\title{
A NOTE ON THE NEUMAN-SÁNDOR MEAN
}

\section{Hui Sun, Tiehong ZhaO, Yuming Chu And BaOyu LiU}

Abstract. In this article, we present several best possible lower bounds for the Neuman-Sándor mean in terms of the geometric combinations of harmonic and quadratic means, geometric and quadratic means, harmonic and contraharmonic means, and geometric and contraharmonic means.

Mathematics subject classification (2010): 26E60.

Keywords and phrases: Neuman-Sándor mean, harmonic mean, geometric mean, quadratic mean, contraharmonic mean.

\section{REFERENCES}

[1] E. Neuman And J. SÁndor, On the Schwab-Borchardt mean, Math. Pannon. 14, 2 (2003), $253-266$.

[2] E. Neuman And J. SÁndor, On the Schwab-Borchardt mean II, Math. Pannon. 17, 1 (2006), 49-59.

[3] E. Neuman, Inequalities for the Schwab-Borchardt mean and their applications, J. Math. Inequal. 5, 4 (2011), 601-609.

[4] Y.-M. LI, B.-Y. Long AND Y.-M. CHU, Sharp bounds for the Neuman-Sándor mean in terms of generalized logarithmic mean, J. Math. Inequal. 6, 4 (2012), 567-577.

[5] Y.-M. CHU AND B.-Y. LonG, Bounds of the Neuman-Sándor mean using power and identric means, Abstr. Appl. Anal. 2013, Article ID 832591, 6 pages.

[6] Z.-Y. HE, W.-M. QiAn, Y.-L. JiAnG, Y.-Q. Song AND Y.-M. CHU, Bounds for the combinations of Neuman-Sándor, arithmetic, and second Seiffert means in terms of contraharmonic mean, Abstr. Appl. Anal. 2013, Article ID 903982, 5 pages.

[7] T.-H. Zhao, Y.-M. Chu, Y.-L. Jiang And Y.-M. Li, Best possible bounds for Neuman-Sándor mena by the identric, quadratic and contraharmonic means, Abstr. Appl. Anal. 2013, Article ID 348326, 12 pages.

[8] Y.-M. Chu, B.-Y. Long, W.-M. Gong And Y.-Q. Song, Sharp bounds for Seiffert and NeumanSándor means in terms of generalized logarithmic means, J. Inequal. Appl. 2013, 10 (2013), 13 pages.

[9] W.-M. QiAn AND Y.-M. CHU, On certain inequalities for Neuman-Sándor mean, Abstr. Appl. Anal. 2013, Article ID 790783, 6 pages.

[10] Y.-M. CHU, T.-H. ZHAO AND B.-Y. LiU, Optimal bounds for Neuman-Sándor mean in terms of the convex combination of logarithmic and quadratic or contra-harmonic means, J. Math. Inequal. (to appear).

[11] W.-D. JIANG AND F. QI, Sharp bounds for Neuman-Sándor mean in terms of the root-mean-square, preprint.

[12] W.-D. JIANG AND F. QI, Sharp bounds in terms of a two-parameter family of means for NeumanSándor mean, preprint.

[13] E. NEUMAN, On some means derived from the Schwab-Borchardt mean, J. Math. Inequal. (to appear).

[14] E. NEumAn, On some means derived from the Schwab-Borchardt mean II, J. Math. Inequal. (to appear).

[15] E. Neuman, A note on a certain bivariate mean, J. Math. Inequal. 6, 4 (2012), 637-643.

[16] T.-H. Zhaо, Y.-M. CHU AND B.-Y. LiU, Optimal bounds for Neuman-Sándor mean in terms of the convex combinations of harmonic, geometric, quadratic, and contraharmonic means, Abstr. Appl. Anal. 2012, Article ID 302635, 9 pages.

[17] E. NEUMAN AND J. SÁNDOR, Bounds for the quotients of differences of certain bivariate means, Adv. Stud. Contemp. Math. 23, 1 (2013), 61-67. 
[18] G. D. Anderson, M. K. Vamanamurthy And M. Vuorinen, Confromal Invariants, Inequalitiesm and Quasiconformal Maps, New York, John Wiley \& Sons, 1997.

[19] S. SimiĆ AND M. VUORINEN, Landen inequalities for zero-balanced hypergeometric functions, Abstr. Appl. Anal. 2012, Article ID 932061, 11 pages. 